\title{
Population genetic structure of
}

\section{an extremely logged tree species \\ Guaiacum sanctum L. In the Yucatan Peninsula, Mexico}

Botanical Sciences 94 (2): 345-356, 2016

DOI: $10.17129 /$ botsci.278

\author{
Ken Oyama ${ }^{1,3}$, Miguel Martínez-Ramos², Juan Manuel Peñaloza-Ramírez², \\ Víctor Rocha-Ramírez², Esmeralda G. Armenta-Medina² and Paulina \\ HERNÁNDEZ-SOTO ${ }^{1,2}$
}

\begin{abstract}
Habitat disturbance in tropical forests has affected the viability of several tree species. In Mexico, populations of Guaiacum sanctum have disappeared in some regions due to a strong habitat reduction which could endanger the genetic diversity and connectivity of remnant populations. In this study, 17 populations from the Yucatán Peninsula were analyzed with seven nuclear microsatellites. Several parameters describing the genetic diversity were estimated. The genetic structure was evaluated using Bayesian cluster analysis. Population bottlenecks, effective population size, and genetic connectivity were estimated. Populations of G. sanctum showed high values of genetic diversity. Two genetic groups with contrasting distributions were detected, the first one located in northern Yucatán and Quintana Roo and the second, in southern Campeche. Evidence of population bottleneck was detected only for Campeche populations. Also, we found indications of significant levels of inbreeding and a low effective population size. The connectivity analysis revealed exchange among populations of $G$. sanctum but the habitat fragmentation may act to impede gene flow, contributing to the division observed between clusters. This genetic differentiation was possibly caused by environmental pressures, although effects of historical extensive logging practices occurred in southern Mexico during the last few decades cannot be discarded. Fragmentation has a negative effect on ecosystem services and on the availability of favorable sites for seedling establishment, which could disturb pollination and dispersion processes, modifying in the long term the effective population size.
\end{abstract}

Key words: Bayesian clustering, connectivity, Guaiacum sanctum, genetic diversity and structure, population bottleneck.

\section{Estructura genética poblacional de una especie de árbol Guaiacum sanctum L. extremadamente diezmada en la Península de Yucatán, México}

\section{Resumen}

La perturbación del hábitat en los bosques tropicales ha afectado la viabilidad de varias especies de árboles. En México, poblaciones de Guaiacum sanctum han desaparecido en algunas regiones debido a una fuerte reducción del hábitat poniendo en peligro la diversidad genética y conectividad de las poblaciones remanentes. En este estudio, 17 poblaciones de la Península de Yucatán se analizaron con siete loci de microsatélites nucleares. Se estimaron varios parámetros de diversidad genética. La estructura genética fue evaluada usando un análisis de agrupamiento Bayesiano. Fueron estimados cuellos de botella y tamaños efectivos poblacionales y la conectividad genética. Las poblaciones de G. sanctum mostraron latos valores de diversidad genética. Se detectaron dos grupos genéticos con distribuciones contrastantes, el primero en el norte de Yucatán y Quintana Roo y el segundo en el sur de Campeche. Evidencias de cuello de botella fueron detectadas solo en las poblaciones de Campeche. También se encontraron niveles significativos de endogamia y un bajo tamaño efectivo poblacional. El análisis de conectividad reveló intercambio entre poblaciones de G. sanctum pero la fragmentación de los hábitats pueden actuar para impedir el flujo de genes, contribuyendo a la división observada entre grupos. Esta diferenciación genética fue causada posiblemente por presiones ambientales, aunque no se puede descartar los efectos de las prácticas extensas de extracción históricas que ocurrieron en el sur de México en las últimas décadas. La fragmentación tiene un efecto negativo en los servicios de los ecosistemas y la disponibilidad de sitios favorables para el establecimiento de plántulas, lo que podría perturbar los procesos de polinización y dispersión, modificando en el largo plazo, el tamaño efectivo de las poblaciones.

Palabras clave: Agrupamiento Bayesiano, conectividad, Guaiacum sanctum, cuellos de botella poblacional, diversidad y estructura genética. 
reservation of genetic diversity and the maintenance of the evolutionary potential in tropical species are of key importance to maintain the probability of population persistence (Lowe et $a l ., 2005)$. Therefore, studies on conservation genetics are very important to evaluate the effects of habitat destruction on population connectivity (Farwig et al., 2008; Griffiths et al., 2008). Habitat degradation could affect the ability of populations to respond to environmental changes (Young and Clarke, 2000; Jacquemyn et al., 2012), reducing population genetic variability and affecting long term establishment (Fahrig 2003; Lowe et al., 2005). Habitat destruction in the tropical and subtropical forests has been one of the main causes of vulnerability of tropical ecosystems (Trejo and Dirzo, 2000; Lowe et al., 2005). Several species show a reduction in their genetic diversity and in the connectivity between populations, and an increase in their levels of inbreeding (Andre et al., 2008; Moreira et al., 2009; Young and Pickup, 2010).

The species of the genus Guaiacum L. have been logged due to their economic value as wood. Six of these tree species have been reported in Florida, Mexico, Central America, and the Caribbean Islands (Grow and Schwartzman, 2001; Martínez and Galindo-Leal, 2002). Due to the extreme logged practices in at least 11 countries, Guaiacum species have been declared as endangered or almost extinct (CITES 2000; Chavarría et al., 2001; Vivero et al., 2006). Guaiacum sanctum L. has been classified as threatened species in Mexico since 1994 (NOM-059SEMARNAT 2002; González-Espinosa, 2009), but López-Toledo et al. (2008, 2011) proposed that $G$. sanctum should be considered as endangered species because it is one of the most largely harvested tree species during the past few decades (Oldfield, 2004). Furthermore, a dramatic and progressive loss of its habitat in $28.2 \%$ in the last few generations has been reported (IUCN 2010; Dertien and Duval, 2009; López-Toledo et al., 2008).

In recent years, the exportation of Guaiacum timbers has declined gradually in Mexico due to a lower demand explained by the use of new available substitute woods in the market (Oldfield, 2004; Vivero et al., 2006). Natural forests have been reduced by clearing and deforestation for agriculture and the development of hotels and resorts in the Yucatán Peninsula (Grow and Schwartzman, 2001; Vester et al., 2007; González-Espinosa, 2009). However, it is unknown how such deforestation rates have impacted the amount of genetic diversity, structure, and connectivity between populations of $G$. sanctum in the Yucatán Peninsula. We expected to find lower levels of genetic diversity on remnant populations, a moderate genetic differentiation between populations as a product of restricted gene flow, evidence of inbreeding, signals of population bottleneck, and changes in the effective population size than populations in undisturbed landscapes.

\section{Material and methods}

Study species. Guaiacum sanctum (Zygophyllaceae) is a slow-growing tree distributed in tropical and subtropical forests from northern Costa Rica to southeast Mexico, the Florida Keys, and the Caribbean Islands (Holdridge et al., 1975). In Mexico, G. sanctum is distributed in the states of Oaxaca, Chiapas, Quintana Roo, Yucatán and Campeche. It is an evergreen tree that grows up to $25-30 \mathrm{~m}$ in height and $60 \mathrm{~cm}$ diameter at breast height (dbh). Its compound leaves are paripinnate and opposite with 4-12 oblong to obovate leaflets. Perfect flowers are solitary or in terminal panicles with blue-violet petals $0.7-1.2 \mathrm{~cm}$ long and yellow stamens. Flowering occurs between March and July. Wasps and bees are the reported pollinators. Fruits are capsules $1.5-2.0 \mathrm{~cm}$ long, winged, that turn yellow-orange when ripe. Seeds are enclosed by an intensely red aril, which attract birds, the main dispersers (Chavarría et al., 2001; Grow and Schwartzman, 2001).

Sampling. Within the Yucatán Peninsula 17 populations of Guaiacum sanctum were sampled as follows: six in Yucatán, three in Quintana Roo, and eight in Campeche (Figure 1). On average, from 7-10 individuals were sampled. In most of the cases, we collected the remaining reproductive individuals. In denser populations such as some populations of Campeche State, we randomly chosen ten reproductive trees with at least $10 \mathrm{~m}$ of separation among trees. Leaf samples were frozen until genetic analysis. Genomic DNA from each individual was extracted from 100 $\mathrm{mg}$ of frozen leaf following the protocol proposed by Lefort and Douglas (1999). Seven nuclear 
Figure 1. Potential geographic distribution of Guaiacum sanctum in Mexico. Red dots represent the localities obtained in Herbarium specimens and GBIF web site.

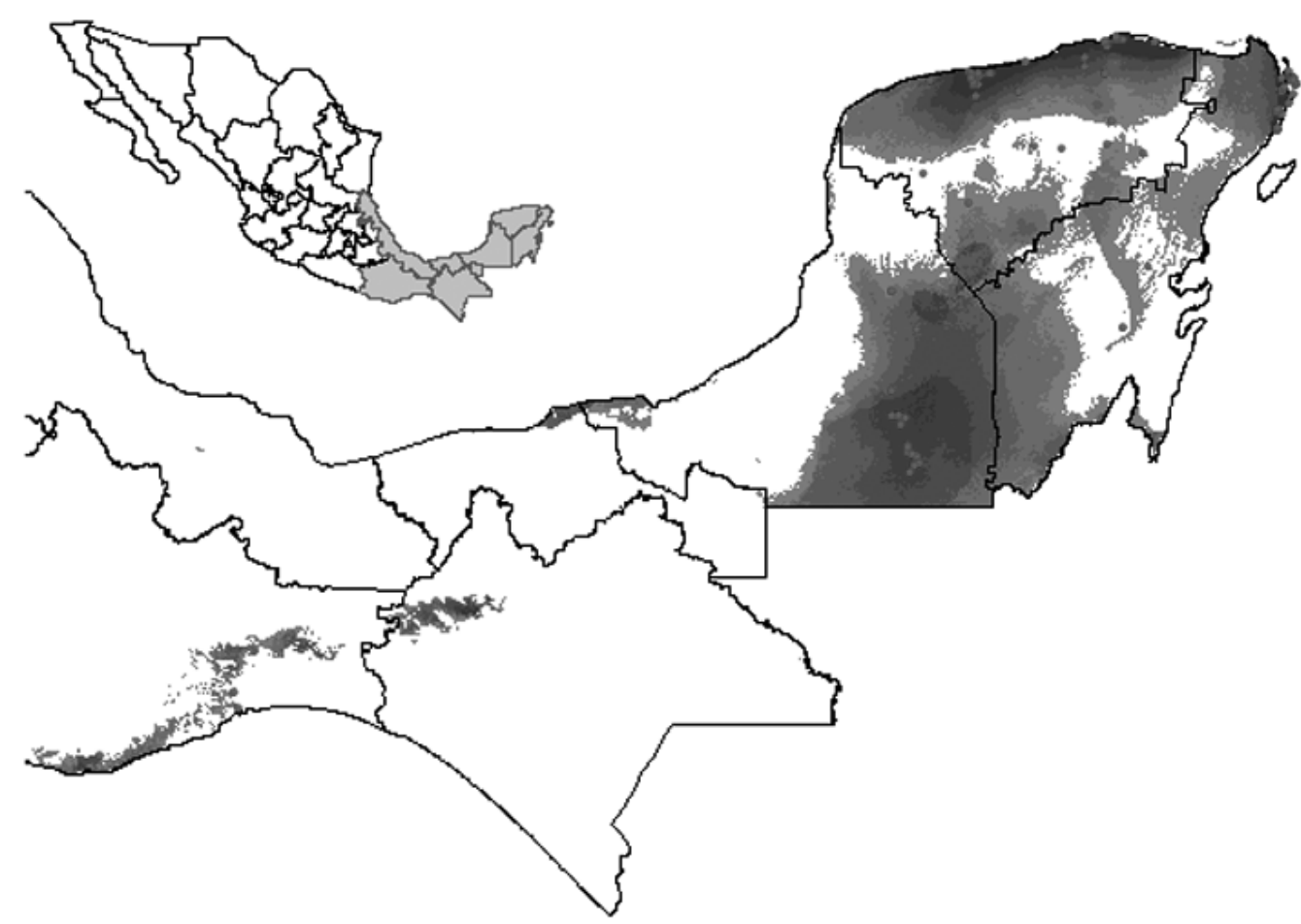

DNA (nSSR) microsatellite loci were selected and amplified in multiplex polymerase chain reactions (PCR). Two groups of primers were arranged according to allele size and fluorescent labels. The first group was formed by the primers pairs for Gcoult_1, Gcoult_2 and Gcoult_5, whereas the second group included the primer pairs for Gcoult_10, Gcoult_12, Gcoult_14 and Gcoult_15 (McCauley et al., 2008). PCR was performed using the QIAGEN Multiplex PCR kit (QIAGEN) in a volume of $5 \mu \mathrm{l}$ containing $1 \mathrm{X}$ Multiplex PCR Master Mix, $2 \mu \mathrm{M}$ each primer, $\mathrm{dH} 2 \mathrm{O}$, and $20 \mathrm{ng}$ template DNA. The thermal cycling conditions consisted of 40 cycles, each at $95{ }^{\circ} \mathrm{C}$ for $1 \mathrm{~min}$, annealing for $1 \mathrm{~min}$ (i.e. first and second primer groups $58^{\circ} \mathrm{C}$ and $60{ }^{\circ} \mathrm{C}$, respectively), extension for $2 \mathrm{~min}$ at $72{ }^{\circ} \mathrm{C}$ and a final extension at $72{ }^{\circ} \mathrm{C}$ for $10 \mathrm{~min}$. Multiplex PCR products were combined with a GeneScan-500 LIZ size standard and ran in an ABI-PRISM 3100 Avant sequencer (Applied Biosystems). Fragments were analyzed and registered with the Peak Scanner program 1.0 (Applied Biosystems).

Genetic diversity. To test for the presence of null alleles, upper alleles dropout or errors due to stutter in the microsatellite data obtained from all the individuals of 17 populations of Guaiacum sanctum, the MICRO-CHECKER 2.2.3 software was used (Van Oosterhout et al., 2004) with $10^{2}$ bootstrap simulations and a $95 \%$ confidence interval. We also tested departures from Hardy-Weinberg equilibrium (e.g. heterozygosity excess and deficit $F_{I S}$ ) with the GENEPOP 4.1 software (Raymond and Rousset, 1995) using the Markov-chain approach (e.g. $10^{3}$ dememorization steps, $10^{2}$ batches and $10^{3}$ iterations per batch). Additionally, we estimated the effective number of alleles $\left(N_{e}\right)$, observed heterozygosity $\left(H_{O}\right)$, and expected heterozygosity $\left(H_{E}\right)$ for each population were performed with $10^{3}$ iterations using GENETIX 4.05 program (Belkhir et al., 1996-2004).

Genetic structure. A Bayesian cluster analysis was conducted using STRUCTURE version 2.3.3 (Pritchard et al., 2000; Falush et al., 2003; Hubisz et al., 2009). In this approach, individuals were assigned probabilistically to one of the predefined $K$ populations (gene pools) to identify the optimal number of genetic groups (Evanno et al., 2005). The optimum number of groups $(K)$ was determined by varying the value of $K$ from 1 to 10 and running the analysis ten times per $K$ value to determine the maximum value of posterior likelihood [LnP (D)]. Each run was performed using $50^{4}$ burn-in periods and $10^{6}$ Markov Chain Monte Carlo (MCMC) repetitions 
after burn-in. We used a model allowing admixture with correlated allelic frequencies without any prior information. Also, we determined the most probable value of $\mathrm{K}$ using the maximum value of $\Delta K$ according to Evanno et al. (2005) implemented in the program Structure Harvester 0.6.1 (Earl and vonHoldt, 2012). A hierarchical test of population structure was estimated using both mutation models [i.e. stepwise mutation model (SMM), the infinite allele model (IAM)] performed with AMOVA in ARLEQUIN 3.5. (Excoffier et al., 2005). The variance distribution between groups, among populations between groups, and within populations was compared. The statistical significance was tested using $10^{4}$ permutations utilizing the resulting groups of genotypes obtained by STRUCTURE.

To identify possible geographic and genetic discontinuities among populations of Guaiacum sanctum, we used the Monmonier's maximum difference algorithm with BARRIER version 2.2 (Manni et al., 2004). This program creates a map of the sampling locations from geographical coordinates, where barriers are represented on the map by identifying the maximum values within the population pairwise genetic distance. We used a matrix of average square distance (ASD) (Goldstein et al., 1995; Slatkin, 1995), estimated for the 17 populations of G. sanctum. Resampling random subsets of individuals within populations provided 100 bootstrap replicate distances that were constructed utilizing MSA program (Dieringer and Schlötterer, 2003) to achieve statistical significance for the predicted barriers.

The connectivity among Guaiacum sanctum populations was analyzed using the POPGRAPH software (http://dyerlab.bio.vcu.edu/software.html). This analysis creates a network of population linkages and describes the amount of genetic variation within populations (Dyer and Nason, 2004). In the POPGRAPH framework, the set of nodes represents sampled populations, and the edges represent the multivariate measures of genetic covariance among populations. The difference in node size reflects differences in within-population genetic variability, while the edge length represents the among-population component of genetic variation due to the connecting nodes. Thus, this analysis examines specifically the connections among individual populations that maintain genetic connectivity among all populations (Dyer and Nason, 2004). POPGRAPH identifies pairs of populations where long distance migration may have occurred by indicating population pairs with significantly greater inter-site distances (Dyer et al., 2010). It also identifies pairs of populations that are located significantly closer than predicted by inter-site separation, which suggests that a direct barrier might exist between the linear distances.

Population size change and bottleneck detection. The software BOTTLENECK 1.2 (Piry et al., 1999) was used to detect recent population bottlenecks that could be defined as a population where the rare alleles are the first to be lost decreasing the mean number of alleles per locus. In contrast, heterozygosity is less affected, producing a transient excess in heterozygosity relative to that expected given the resulting number of alleles (Cornuet and Luikart, 1996; Luikart and Cornuet, 1998). To test the data set, we used $90 \%$ stepwise and $10 \%$ multistep mutations $10^{4}$ iterations with the Wilcoxon signed-rank test, and the stepwise mutation (SMM), the infinite allele (IAM) and two-phase mutation (TPM) models. Additionally, we also estimated the effective population size in populations of G. sanctum with the program LDNe (Waples and Do, 2008), which implements the bias-correction method developed by Waples (2006) to obtain $N_{e}$ from each sample of individuals. For LDNe, we used the criterion Pcrit $=0.02$ (alleles with frequency $<0.02$ are excluded), which generally provides a good balance among accuracy and bias (Waples and Do, 2009). Confidence intervals (CIs) for Ne were based in the chi-square approximation implemented by LDNe (Waples, 2006).

\section{Results}

Genetic diversity. We did not find evidence for null alleles overall sample-loci combinations, and tests for error due to stutter and upper allele dropout resulted negatives in all cases. Populations of Guaiacum sanctum in the Yucatán Peninsula had, on average, 26.4 alleles for the seven loci. Average number of alleles per locus indicated that the loci Gcoult_1, 5, 10, 12 were the most polymorphic (e.g. 7.94, 7.88, 6.17 and 7.88, respectively), then followed moderate to low polymorphism shown by the loci Gcoult_2, 14, 15 (e.g. 3.29, 5.94 and 5.29, respectively). The 
Table 1. Nuclear microsatellite (i.e. nSSR) parameters of genetic diversity and the exact test of Hardy-Weinberg equilibrium estimated in 17 populations of G. sanctum in the Yucatán Peninsula Mexico.

\begin{tabular}{|c|c|c|c|c|c|c|c|}
\hline Population & $N$ & $\mathrm{Ne}$ & Private alleles & $H_{O}$ (s.d.) & $H_{E}$ (s.d.) & $H W(\mathrm{HD})$ & $H W(\mathrm{HE})$ \\
\hline Yucatan 1 & 10 & 6.71 & 226,131 & $0.828(0.160)$ & $0.735(0.155)$ & n.s. & (2) $0.03 * *$ \\
\hline Yucatan 3 & 10 & 8.0 & $242,216,230$ & $0.800(0.152)$ & 0.830(.096) & (14) $0.02 * *$ & n.s. \\
\hline Yucatán 4 & 10 & 8.42 & $264,236,260$ & $0.723(0.097)$ & $0.839(.080)$ & $(5,6) 0.003^{* *}$ & n.s. \\
\hline Yucatán 6 & 10 & 6.71 & $250,174,153$ & 0.742(.190) & $0.769(.105)$ & (1) $0.04^{* *}$ & (2) $0.005^{* *}$ \\
\hline Total & & 7.56 & 23 & 0.790 & 0.80 & & \\
\hline Quintana Roo 1 & 11 & 6.71 & $159,173,193$ & $0.550(.241)$ & $0.755(.126)$ & $(1,2,12) 0.0001^{* *}$ & n.s. \\
\hline Quintana Roo 2 & 8 & 5.85 & $175,143,163$ & $0.632(.214)$ & $0.755(.230)$ & $(1,15) 0.03^{* *}$ & n.s. \\
\hline Quintana Roo 3 & 10 & 6.57 & $255,229,158$ & $0.623(.267)$ & $0.731(.285)$ & (12) $0.04 * *$ & n.s. \\
\hline Campeche 2 & 10 & 5.0 & 258,204 & $0.657(.214)$ & $0.733(.160)$ & $(12,14) 0.001^{* *}$ & (15) $0.03^{* *}$ \\
\hline Campeche 3 & 10 & 6.14 & $245,169,254$ & $0.637(.179)$ & $0.756(.160)$ & (12) $0.0001^{* *}$ & n.s. \\
\hline Campeche 4 & 10 & 6.14 & $360,158,178$ & 0.560(.199) & $0.797(.067)$ & $(1,2,5,12) 0.001^{* *}$ & n.s \\
\hline Campeche 5 & 10 & 5.42 & $258,243,238$ & $0.665(.101)$ & $0.761(.101)$ & $(5,12) 0.003^{* *}$ & n.s \\
\hline Campeche 6 & 10 & 6.42 & 245,247 & $0.741(.211)$ & $0.766(.109)$ & (12) $0.004^{* *}$ & (12) $0.004^{* *}$ \\
\hline Campeche 7 & 10 & 5.42 & 213 & $0.622(.274)$ & $0.735(.176)$ & (5) $0.004 * *$ & n.s. \\
\hline Campeche 8 & 7 & 4.42 & 265,164 & $0.659(.268)$ & $0.720(.169)$ & (12) $0.01^{* *}$ & n.s. \\
\hline Total & & 5.42 & 21 & 0.630 & 0.740 & & \\
\hline
\end{tabular}

average number of alleles per locus per population and the observed and expected heterozygosity $\left(H_{O}\right.$ and $\left.H_{E}\right)$ were higher in populations from Yucatán $\left(N_{e}=7.56, H_{O}=0.790, H_{E}=0.80\right)$ followed by populations in Quintana Roo (e.g. $N_{e}=6.37, H_{O}=0.600, H_{E}=0.750$ ), and Campeche (e.g. $N_{e}=5.42, H_{O}=0.630, H_{E}=0.740$; Table 1). Significant deviation from Hardy-Weinberg equilibrium due to heterozygosity excess was observed in the loci Gcoult-2 and 15, whereas heterozygosity deficiency was more frequent in the locus Gcoult-1, 2, 5, 6, 12, 14 and 15 (Table $1)$. The highest positive values of the coefficient of endogamy $\left(F_{I S}\right)$ (i.e. heterozygote deficit) were observed in populations from Quintana Roo $\left(F_{I S}=0.182 ; P=0.001\right)$, whereas in populations from Campeche $\left(F_{I S}=0.035 ; P=0.001\right)$ and Yucatán $\left(F_{I S}=0.003 ; P=0.001\right)$ significant negative values for $F_{I S}$ were observed (i.e. heterozygote excess; Table 1).

Genetic structure. The highest posterior probability obtained from Bayesian likelihood [LnP (D)] and $\Delta K$ with the Evanno et al. (2005) approach, revealed that $K=2$ is the effective number of genetic clusters. Cluster 1 (in red) was more common in the populations from Yucatán and Quintana Roo whereas the Cluster 2 (in green) was well represented in populations from Campeche (Figure 2). Hierarchical analysis of molecular variance (AMOVA), performed for both mutation models (i.e. $F_{S T}$ and $R_{S T}$ ), indicated that most of the genetic variation resided within populations $\left(\Phi_{S T}=88.2 \%, P=0.001 ; \Phi_{S T}=89.5 \%, P=0.001\right)$ followed by variation among populations within groups $\left(\Phi_{S C}=8.7 \%, \stackrel{\mathrm{P}}{=}=0.001 ; \Phi_{S C}=6.7 \%, P=0.001\right)$, while the differentiation among groups only accounted for the remaining variation $\left(\Phi_{C T}=2.9 \%, P=\right.$ 0.001 and $\Phi_{C T}=3.6 \%, P=0.001$; Table 2).

Seven barriers with more than $50 \%$ bootstrap support were detected (Figure 2). Single barriers were observed, such as Barrier 1 that divided Quintana Roo 3 from the rest of the populations, the Barriers 2 and 3 that divided Yucatán 1 from Yucatán 2, and this one from other populations of Yucatán, respectively, whereas Barrier 6 splitted Campeche 7 from Quintana Roo1. Barriers 4 and 7 divided red genotypes in northern populations (i.e. Yucatán and Quintana Roo) 
Table 2. Analysis of molecular variance (AMOVA) performed on the nSSR data and using $F_{S T}$ and $R_{S T}$ for the two group genetic clusters obtained by means of STRUCTURE for populations of Guaiacum sanctum. Asterisks indicate statistically significant values $(P<0.01)$. Tests were based on $10^{4}$ random permutations.

\begin{tabular}{|c|c|c|c|c|c|}
\hline & Source of variation & SS & $\begin{array}{l}\text { Variance } \\
\text { components }\end{array}$ & $\begin{array}{l}\text { Percentage } \\
\text { of variation }\end{array}$ & Fixation index \\
\hline \multicolumn{5}{|l|}{$\overline{F_{S T}}$} & $\Phi_{\mathrm{CT}}=0.029^{* * *}$ \\
\hline & $\begin{array}{l}\text { Among populations } \\
\text { within groups }\end{array}$ & 108.78 & 0.268 & 8.7 & $\Phi_{\mathrm{SC}}=0.087^{* * *}$ \\
\hline & Within populations & 764.970 & 2.693 & 88.2 & $\Phi_{\mathrm{ST}}=0.882^{* * *}$ \\
\hline & Total & 893.624 & 3.050 & & \\
\hline & $R_{S T}$ & $5,696.8$ & 31.662 & 3.6 & $\Phi_{\mathrm{CT}}=0.036^{* * *}$ \\
\hline & $\begin{array}{l}\text { Among populations } \\
\text { within groups }\end{array}$ & $24,935.8$ & 58.151 & 6.7 & $\Phi_{\mathrm{SC}}=0.067^{* * *}$ \\
\hline & Within populations & 212,482 & 770.167 & 89.5 & $\Phi_{\mathrm{ST}}=0.895^{* * *}$ \\
\hline & Total & 243,114 & 859.981 & & \\
\hline
\end{tabular}

Figure 2. Each pie chart represents the proportions in each population of the two genetic groups as assigned by the program STRUCTURE. Green Genotype and red Genotype are representing the genetic ancestry groups corresponding to $G$. sanctum populations. Genetic discontinuities (bold lines B-1-7) obtained with Monmonier's maximum difference algorithm on genetic distances derived from microsatellite allele frequencies.

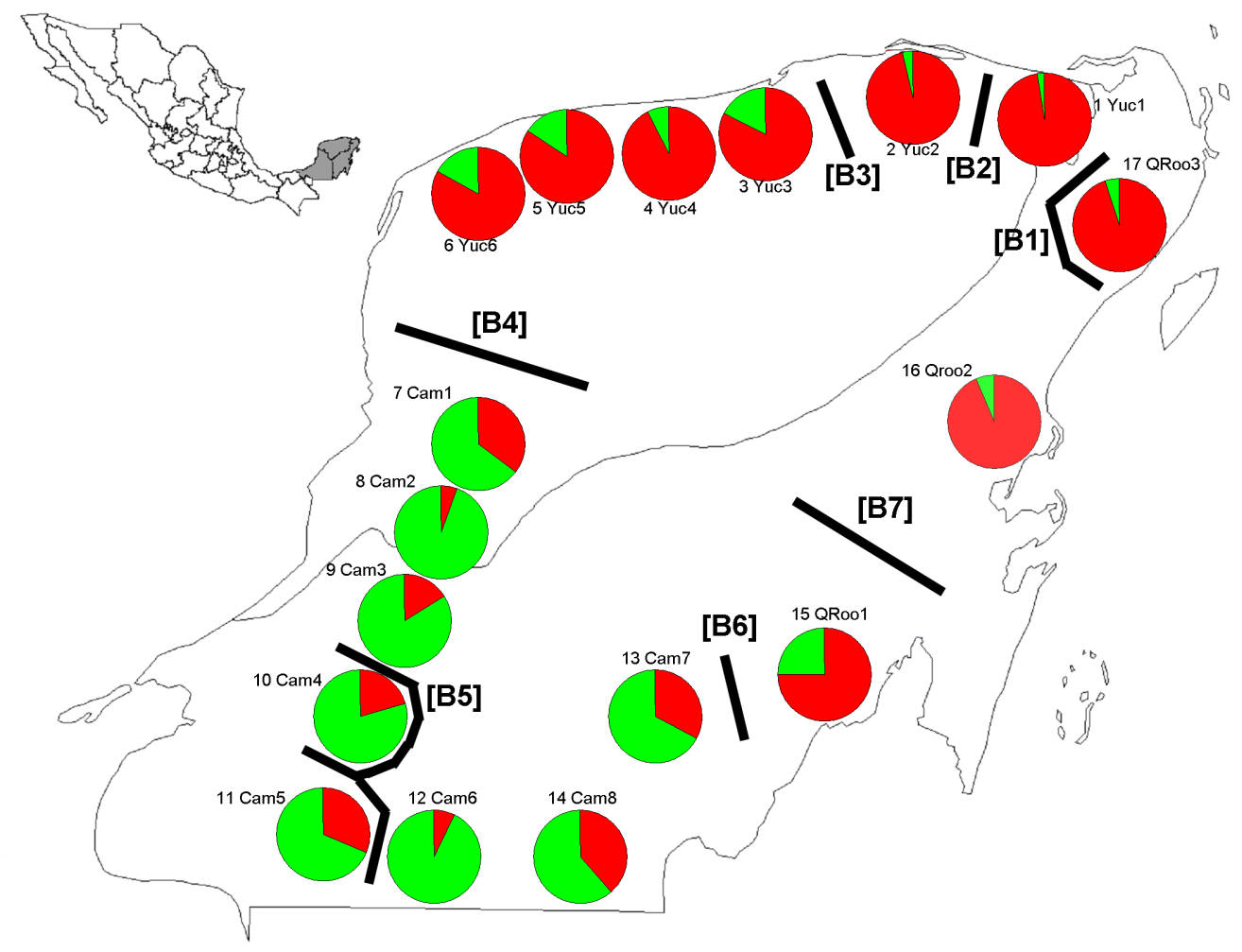

from green genotypes observed in southern populations from Campeche. Finally, the Barrier 5 is a complex barrier that divided population from Campeche 4 and Campeche 5 from the rest of the populations (Figure 2).

The POPGRAPH network of populations based on nSSR genotypes had 17 edges out of the 22 possible ones and indicates extensive historical connectivity among most populations (Figure 3). The most common colonization patterns occurs in a north- south axis along Yucatán and Quintana Roo throughout southern portions of Campeche to the Calakmul Reserve, but it is not uncommon to see east-west gene exchanges, especially across the north-east to the south-west part of the species range. Our data indicate occasional long distance gene exchange across the central portion of Campeche to the north of Yucatán where the genotypes 
Figure 3. Map of inter-population genetic structure computed from seven microsatellite loci in G. sanctum, implemented in the PopGraph R package. Populations are represented by nodes connected by the minimal set of edges that sufficiently describes the total among-population covariance structure. Circles represent the differences in node size that reflects the within and between populations differences in their heterozygosities. Numbering of populations is as in Table 1.

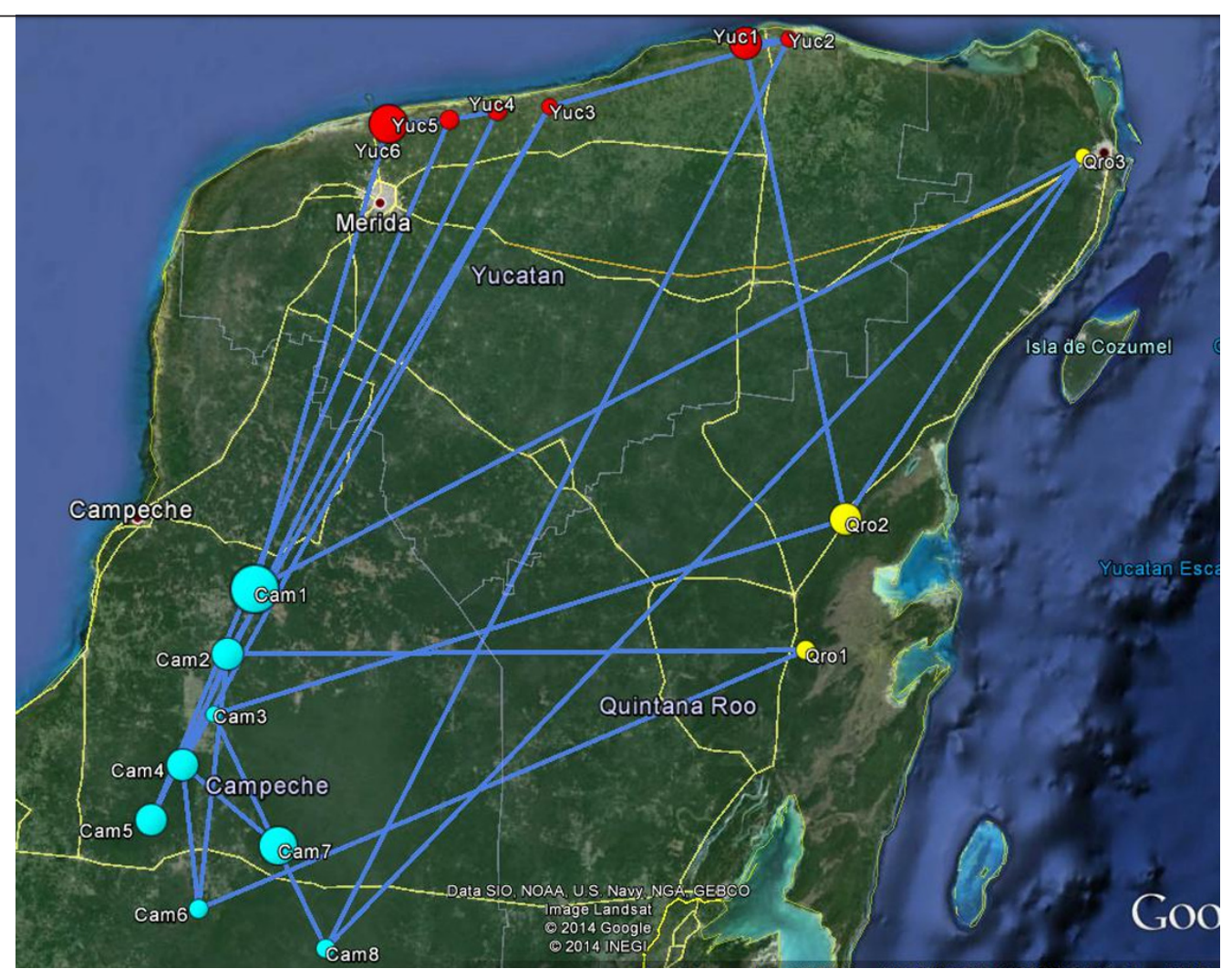

Table 3. Bottleneck analysis for G. sanctum populations in the Yucatán Peninsula using Wilcoxon rank test under infinite allele, stepwise mutation and two phase model. Parameters for TPM: variance $=10 \%$, proportion of $\mathrm{SMM}=90 \%$, estimation based on 104 replications. P, probability. IAM, infinite allele model; TPM, two phase model; SMM, stepwise mutation model. ${ }^{*}$ Indicate significant deviation from equilibrium as value less than 0.05 . Also, we include the results obtained for the estimation of the population effective size for Yucatan, Campeche and Quintana Roo populations. Values obtained with the program LDNe.

\begin{tabular}{llll} 
Models & Yucatán & Campeche & Quintana Roo \\
\hline IAM & 0.468 & $0.039^{* *}$ & 0.187 \\
TPM & 0.988 & 0.992 & 0.996 \\
SMM & 0.988 & 1.000 & 0.996 \\
LDNe & 262 & 123 & 100
\end{tabular}

are significantly more similar than expected based on spatial distance. Our analysis also identifies a great amount of network connection between the Campeche and Quintana Roo, but not much connectivity with Yucatán that resulted more genetically dissimilar than predicted by spatial distance (Figure 3).

Bottleneck detection and population size change. The results of detection of a recent bottleneck in populations of Guaiacum sanctum in Yucatán and Quintana Roo were non-significant $(P<$ 0.50 ) for any of the models (IAM, TPM and SMM) analyzed. Populations of Campeche exhibited evidence of bottleneck only with the IAM $(P=0.039)$ (i.e. particularly in the loci Gcoult_2 and 5), but not with the models TPM and SMM (Table 3).

The results of estimation of effective population size $\left(N_{e}\right)$ performed with the program LDNe in populations of Guaiacum sanctum showed that Yucatán populations had the highest values ( $N_{e}=262$ individuals), followed by populations of Campeche $\left(N_{e}=123\right)$ and Quintana Roo $\left(N_{e}=100\right)$; in all cases, estimates had high Jackknife support and a good confidence interval (CIs) (Table 3). 


\section{Discussion}

Current situation of Guaiacum sanctum. López-Toledo et al. (2011) modeled the ecological niche of $G$. sanctum to know the historical changes in the extent of available habitat and to project future trends on the basis of contemporary rates of habitat loss. They found strong evidence of habitat loss in the states of Oaxaca, Chiapas, northern Yucatán and Quintana Roo. These results assessed the negative effects of dramatic changes in land use across southern and eastern Mexico during the last two decades (Miles et al., 2006). In Mexico, G. sanctum has suffered a considerably habitat loss of about $28.2 \%$ in the last decades and a great reduction in population size (López-Toledo et al., 2008, 2011). Possible causes can be attributed to a rapid increase in deforestation rates, selective removal of trees in forest fragments, changes of forest use to agriculture or pasture for cattle raising, and other human activities (Oldfield, 2004; López-Toledo et al., 2008).

Genetic diversity. Previous studies on a related endemic species, Guaiacum unijugum from the Cape region in Baja California, Mexico, showed low values of genetic diversity $\left(N_{e}=1.076\right.$, $H_{E}=0.070, H_{O}=0.073$ ) obtained with nuclear microsatellite loci (McCauley et al., 2010). Populations of G. unijugum are also endangered due to human activities such as tourism and excessive logging. In contrast, in our study and using the same nuclear microsatellite loci, we found higher levels of genetic diversity in all populations of G. sanctum (Table 1) than G. unijugum, despite the fact that some populations at Yucatán Peninsula are strongly affected by forest fragmentation. Current levels of genetic diversity indicate that enough number of individuals of G. sanctum escape logging retaining moderate to high levels of genetic diversity, suggesting that only rare and low frequency alleles were lost. Populations of G. sanctum still had different private alleles in each region (Table 1). Therefore, we suggested that the effect of a recent habitat fragmentation processes, like in our case, may have left a moderate signature in the genetic diversity of this species as were also previously reported in other tree species (Aguilar et al., 2008; Moreira et al., 2009; Figueroa-Esquivel et al., 2010).

Additionally, we observed the highest positive values of endogamy $F_{I S}$ in populations from Quintana Roo $\left(F_{I S}=0.182, P=0.001\right)$, whereas in populations from Campeche and Yucatán both significant positive values (i.e. heterozygote deficit) and negative (i.e. heterozygote excess) for $F_{I S}$ index were observed (Table 1). The deficit of heterozygotes in populations out of HardyWeinberg equilibrium indicates the existence of biotic and abiotic factors causing change during the periods of pre-and post-disturbance populations (Andre et al., 2008; Schaberg et al., 2008; Jacquemyn et al., 2012). Habitat disturbance seems to be one of the factors that caused the isolation of populations from one another, the progressive reduction in pollen flow into stands and the reduction in the population size (Young and Clarke, 2000; Vergeer et al., 2003; Young and Pickup, 2010).

Genetic structure. At the landscape level, the distribution of genetic ancestry in populations of Guaiacum sanctum in southern Mexico showed two groups of populations. Both, STRUCTURE and BARRIERS inferences are coincident and may represent a case of habitat fragmentation or could indicate historic differences associated with the colonization of distinct geographic regions from southern populations. For instance, the Barriers 4 and 7 divides the genetic group 1 (red genotype) in northern populations of Yucatán and Quintana Roo from the genetic group 2 (green genotype) observed in southern populations in Campeche. Even if, we observed very different geographically distributed genotypes, the AMOVA indicated that most of the genetic variation resides within populations while the differentiation among groups only accounted for $F_{S T}\left(\Phi_{C T}=2.9 \%, P=001\right)$ and $R_{S T}\left(\Phi_{C T}=3.6 \%, P=0.001\right)$.

Given the general low genetic differentiation in Guaiacum sanctum, we suggest that the detected genetic connectivity is a consequence of the dispersion ability of this species. Previous studies indicated the potential of G. sanctum for long distance pollen and seed dispersal (Wendelken and Martin, 1987; Fuchs and Hamrick, 2010). The known floral morphology with purple color of petals and yellow anthers suggest pollination by bees and wasps which are able to disperse pollen over quite large distances (Holdridge et al., 1975). Seed dispersion in G. sanc- 
tum occurs mainly by mammals and birds (Fuchs and Hamrick, 2010). The flying capabilities of seed dispersers range between 5 to $10 \mathrm{~km}$ on average in populations of $G$. sanctum in Costa Rica (Wendelken and Martin, 1987; Fuchs and Hamrick, 2010). However, the observed pattern of fragmented habitats may act to impede gene flow due to remaining heterogeneity of the landscape across the Yucatán Peninsula.

Bottleneck detection and population size change. We observed evidence of recent bottleneck only for Campeche populations with the IAM model but not with TPM and SMM models (Table 3). This discrepancy in results between the IAM and TPM and SMM models is the consequence of different heterozygosity expectations at mutation equilibrium (Shaffer, 1981; Luikart and Cornuet, 1998). Given that microsatellite mutation is thought to occur largely through the stepwise process, a combination of the SMM and IAM is expected to provide the best estimate of equilibrium heterozygosity for the bottleneck analysis. The absence of heterozygosity excess using both the strict SMM and the mixed TPM suggest that the contemporary population is at mutation-drift equilibrium (Luikart and Cornuet, 1998). On the other hand, several authors have pointed out that these tests often failed to detect bottlenecks in populations known to have experienced population reductions because they have low statistical power as a result of limited sample size (Piry et al., 1999; Peery et al., 2012). Power to detect significant bottlenecks based on the levels of heterozygosity is generally limited (Williamson-Natesan, 2005; Bouzat, 2010). Therefore, results on bottleneck estimations should be taken with caution.

With respect to the effective population size for Guaiacum sanctum, ecological studies are in agreement with genetic estimates. Both estimations showed a tendency to low population size; populations from Yucatán have the highest $N_{e}=262$ individuals, followed by Campeche with a $N_{e}=123$ individuals and by Quintana Roo populations with a $N_{e}=100$ individuals. Ecological studies registered historically higher densities of large trees of $G$. sanctum (up to $70 \mathrm{~cm}$ diameter at breast height - dbh) in Campeche, Yucatán, Quintana Roo, Oaxaca, and Chiapas, but remaining trees currently available in Campeche do not reach more than $55 \mathrm{~cm}$ in dbh (Oldfield, 2004; López-Toledo et al., 2008). Population densities currently registered in Campeche seems to be acceptable with up to 1,200 potentially reproductive individuals per hectare (López-Toledo et al., 2008). However, towards the edges of its distribution the situation drastically change in Oaxaca, Yucatán, and Quintana Roo with densities of only 150-470 individuals per hectare (Vester et al., 2007; López-Toledo et al., 2008). Also, the reproductive system of G. sanctum seems to be impacted by fragmentation because fruits of trees that occurred at lower densities tend to produce less seeds than in non-fragmented habitats (Vester et al., 2007). According to the rules used by conservation practitioner to estimate the population numbers, 50 individuals are needed to prevent an unacceptable rate of inbreeding, 500 to retain evolutionary potential and 5,000 to ensure overall genetic variability (Franklin, 1980; Frankham, 1996; Leimu et al., 2006; Frakham et al., 2014). Several authors have suggested that population size, plant fitness and genetic diversity are generally associated, which probably due to the negative effects of small population size on genetic variation and plant fitness (Vergeer et al., 2003; Traill et al., 2007). In G. sanctum, despite the severity of habitat fragmentation we observed a moderate effect on population genetic diversity and population bottleneck.

Concluding remarks. Greater population densities of Guaiacum sanctum occurred in porous karst terrain soils which are prevalent in northern Yucatán, the eastern portion of Quintana Roo and the southern portion of Campeche (Orellana et al., 1999). In contrast, very low population densities occurred at the seasonally flooded terrains that prevail in the western portion of Campeche and northern and central Tabasco (Martínez and Galindo-Leal, 2002; López-Toledo et al., 2008; 2011). The current geographic distribution of G. sanctum is the result of combined effects of environmental pressures (i.e., soil types) and extensive habitat loss (White and Hood, 2004; Vester et al., 2007; López-Toledo et al., 2008; 2011) that in turn, may explain the observed population genetic diversity, connectivity and differentiation.

Guaiacum sanctum is facing a high risk of extinction and it has been classified as an endangered species by the International Union for the Conservation of Nature (IUCN) (CITES 2000, Vivero et al., 2006). Successful strategies to conserve this species depend on detailed knowledge 
of the levels and distribution of genetic diversity within and between populations but most importantly we need to protect large fragments of remnant forests such as the population of G. sanctum at the natural biosphere reserve of Calakmul, Campeche to maintain the actual levels of genetic diversity of this species. Smaller fragments are also important to protect in order to maintain the genetic connectivity among populations of different regions in the Yucatán Peninsula.

\section{Acknowledgments}

The authors thank to A.L. Albarrán-Lara and W. Ramírez-Toro for technical support. This research was supported by a grant from CONABIO to MMR.

\section{Literature cited}

Aguilar R., Quesada M., Ashworth L., Herrerías-Diego Y. and Lobo J. 2008. Genetic consequences of habitat fragmentation in plant populations: susceptible signals in plant traits and methodological approaches. Molecular Ecology 17:5177-5188.

André T., Lemes M.R. Grogan J. and Gribel R. 2008. Post-logging loss of genetic diversity in a mahogany (Swietenia macrophylla King, Meliaceae) population in Brazilian Amazonia. Forest Ecology and Management 255:340-345.

Belkhir K., Borsa P., Chikhi L., Raufaste N. and Bonhomme F. 1996-2004. GENETIX 4.05, logiciel sous Windows TM pour la genetique des populations.Montpellier: Laboratoire Genome, Populations, Interactions, CNRS UMR 5171, Universite de Montpellier II. Available at: http://kimura.univ-montp2. fr/genetix/. (Consulted 2014).

Bouzat J.L. 2010. Conservation genetics of population bottlenecks: the role of chance, selection, and history. Conservation Genetics 11:463-478.

Chavarría U., González J. and Zamora N. 2001. Árboles comunes del Parque Nacional Palo Verde, Costa Rica. Instituto Nacional de la Biodiversidad, San José.

CITES 2000: Amendments to Appendices I and II of CITES): Transfer of Guaiacum sanctum from Appendix II to Appendix I. Available at: <https://www.cites.org/eng/cop/11/prop/62.pdf>

Cornuet J.M. and Luikart G. 1996. Description and evaluation of two tests for detecting recent bottlenecks. Genetics 144:2001-2014.

Dertien J. and Duval M.R. 2009. Biogeography and divergence in Guaiacum sanctum (Zygophyllaceae) revealed in chloroplast DNA: implications for conservation in the Florida Keys. Biotropica 41:120-127.

Dieringer D. and Schlötterer C. 2003. Microsatellite analyzer (MSA): a platform independent analysis tool for large microsatellite data sets. Molecular Ecology Notes 3:167-169.

Dyer R.J. and Nason J.D. 2004. Population graphs: The graph theoretic shape of genetic structure. Molecular Ecology 13:1713-1727.

Dyer R.J., Nason J.D. and Garrick R.C. 2010. Landscape modelling of gene flow: Improved power using conditional genetic distance derived from the topology of population networks. Molecular Ecology 19:3746-3759.

Earl D.A. and vonHoldt B.M. 2012. STRUCTURE HARVESTER: a website and program for visualizing STRUCTURE output and implementing the Evanno method. Conservation Genetics Resources 4:359-361.

Evanno G., Regnaut S. and Goudet J. 2005. Detecting the number of clusters of individuals using the software STRUCTURE: a simulation study. Molecular Ecology 14:2611-2620.

Excoffier L., Laval G. and Schneider S. 2005. Arlequin ver. 3.0: an integrated software package for population genetics data analysis. Evolutionary Bioinformatics Online 1:47-50.

Fahrig L. 2003. Effects of habitat fragmentation on biodiversity. Annual Review of Ecology, Evolution and Systematics 34:487-515.

Falush D., Stephens M. and Pritchard J.K. 2003. Inference of population structure using multilocus genotype data: linked loci and correlated allele frequencies. Genetics 164:1567-1587.

Farwig N., Braun C. and Böhning-Gaese K. 2008. Human disturbance reduces genetic diversity of an endangered tropical tree, Prunus africana (Rosaceae). Conservation Genetics 9:317-326.

Figueroa-Esquivel E.M., Puebla-Olivares F., Eguiarte L.E. and Núñez-Farfán J. 2010. Genetic structure of a bird-dispersed tropical tree (Dendropanax arboreus) in a fragmented landscape in Mexico. Revista Mexicana de Biodiversidad 81:789-800.

Frankham R. 1996. Relationship of genetic variation to population size in wildlife. Conservation Biology 10:1500-1508.

Frankham R., Bradshaw C.J.A. and Brook B.W. 2014. Genetics in conservation management: Revised 
recommendations for the 50/500 rules, Red list criteria and population viability analyses. Biological Conservation 170:56-63.

Franklin I.R. 1980. Evolutionary change in small populations. In: Soulé M.E. and Wilcox B.A. Eds. Conservation Biology: An Evolutionary-Ecological Perspective, pp. 135-148, Sinauer Associates Inc., Sunderland.

Fuchs E.J. and Hamrick J.L. 2010. Spatial genetic structure within size classes of the endangered tropical tree Guaiacum sanctum (Zygophyllaceae). American Journal of Botany 97:1200-1207.

Goldstein D.B., Ruiz-Linares A., Cavalli-Sforza L.L. and Feldman M.W. 1995. An evaluation of genetic distances for use with microsatellite loci. Genetics 139:463-471.

González-Espinosa M. 2009. Guaiacum sanctum. IUCN Red List of Threatened Species. IUCN. Gland, Switzerland. Available at: <www.iucnredlist.org> (Consulted: April 10, 2014.

Griffiths A.J.F., Wessler S.R., Lewontin R.C. and Carroll S.B. 2008. Introduction to Genetic Analysis. W.H. Freeman, New York.

Grow S. and Schwartzman E. 2001. The status of Guaiacum species in trade. Medicinal Plant Conservation 7:19-21.

Holdridge L. and Poveda L.. 1975. Árboles de Costa Rica. Volumen I. Centro Científico Tropical, San José.

Hubisz M., Falush D. Stephens M. and Pritchard J. 2009. Inferring weak population structure with the assistance of sample group information. Molecular Ecology Resources 9:1322-1332.

IUCN 2010. IUCN Red List of Threatened Species. Version 2010.4. Available at: http://www.iucnredlist. org (Consulted: February 1, 2010).

Jacquemyn H., De Meester L., Jongejans E. and Honnay O. 2012. Evolutionary changes in plant reproductive traits following habitat fragmentation and their consequences for population fitness. Journal of Ecology 100:76-87.

Lefort F. and Douglas G.C. 1999. An efficient micro-method of DNA isolation from mature leaves of four hardwood tree species Acer, Fraxinus, Prunus and Quercus. Annals of Forest Science 56:259-263.

Leimu R., Mutikainen P., Koricheva J. and Fischer M. 2006. How general are positive relationships between plant population size, fitness and genetic variation? Journal of Ecology 94:942-952.

López-Toledo L., Burslem D., Martínez-Ramos M. and García-Naranjo A. 2008. Non-detrimental findings report on Guaiacum sanctum in Mexico. International Experts Workshop on CITES Non-Detrimental Findings, Cancún. Available at: https://cites.org/sites/default/files/ndf_material/WG1-CS7.pdf (Consulted 01 February 2010).

López-Toledo L., González-Salazar C., Burslem D. and Martínez-Ramos M. 2011. Conservation assessment of the threatened tree species Guaiacum sanctum and $G$ coulteri: historic distribution and future trends in Mexico. Biotropica 43:246-255.

Lowe A., Boshier D., Ward M., Bacles C. and Navarro C. 2005. Genetic resource impacts of habitat loss and degradation; reconciling empirical evidence and predicted theory for Neotropical trees. Heredity 95:255-273.

Luikart G. and Cornuet J.-M. 1998. Empirical evaluation of a test for identifying recently bottlenecked populations from allele frequency data. Conservation Biology 12:228-237.

Manni F., Guérard E. and Heyer E. 2004. Geographic patterns of (genetic, morphologic, linguistic) variation: how barriers can be detected by "Monmonier's algorithm". Human Biology 76:173-190.

Martínez E. and Galindo-Leal C. 2002. La vegetación de Calakmul: descripción, composición y distribución. Boletín de la Sociedad Botánica de México 71:7-32.

McCauley R.A., Cortés-Palomec A.C. and Oyama K. 2008. Isolation, characterization, and cross-amplification of polymorphic microsatellite loci in Guaiacum coulteri (Zygophyllaceae). Molecular Ecology Resources 8:671-674.

McCauley R.A., Cortés-Palomec A. and Oyama K. 2010. Distribution, genetic structure, and conservation status of the rare microendemic species, Guaiacum unijugum (Zygophyllaceae) in the Cape Region of Baja California, Mexico. Revista Mexicana de Biodiversidad 81:745-758.

Miles L., Newton A.C., DeFries R.S., Ravilious C., May I., Blyth S., Kapos V. and Gordon J.E. 2006. A global overview of the conservation status of tropical dry forests. Journal of Biogeography 33:491-505.

Moreira P.A., Fernandes G.W. and Collevatti R.G. 2009. Fragmentation and spatial genetic structure in Tabebuia ochracea (Bignoniaceae) a seasonally dry Neotropical tree. Forest Ecology and Management 258:2690-2695.

Oldfield S. 2004. Analysis of trade in parts and derivatives of Guaiacum species from Mexico. Report prepared for IUCN MPSG. Available at: https://cites.org/common/com/pc/15/X-PC15-04-Inf.pdf (Consulted: February 01, 2010

Orellana R.E., García de Miranda E., Bañuelos I., Balam M., González-Iturbe J.A., Herrera F., and Vidal J. 1999. Climatología de la Península de Yucatán. In: Garcia de Fuentes A., Cordoba J. and Chico P. Eds. 
Received:

October 14th, 2014

Accepted:

February 20th, 2015
Atlas de Procesos Territoriales de Yucatán, pp. 37-52, Universidad Autónoma de Yucatán/CONACYT, Mérida.

Peery M.Z., Kirby R., Reid B.N., Stoelting R., Doucet-Bëer E., Robinson S., Vásquez-Carrillo C., Pauli J.N. and Palsbøll P.J. 2012. Reliability of genetic bottleneck tests for detecting recent population declines. Molecular Ecology 21:3403-3418.

Piry S., Luikart G. and Cornuet J.-M. 1999. BOTTLENECK: a computer program for detecting recent reductions in the effective population size using allele frequency data. Journal of Heredity 90:502-503.

Pritchard J.K., Stephens M. and Donnelly P. 2000. Inference of population structure using multilocus genotype data. Genetics 155:945-959.

Raymond M. and Rousset F. 1995. GENEPOP (version 1.2): population genetics software for exact tests and ecumenicism. Journal of Heredity 86:248-249.

Schaberg P.G., DeHayes D.H., Hawley G.J. and Nijensohn S.E. 2008. Anthropogenic alterations of genetic diversity within tree populations: Implications for forest ecosystem resilience. Forest Ecology and Management 256:855-862.

SEMARNAT (Secretaría del Medio Ambiente y Recursos Naturales). 2002. Norma Oficial Mexicana NOM-059-ECOL-2001. Protección ambiental, especies nativas de México de flora y fauna silvestres, categorías de riesgo y especificaciones para su inclusión, exclusión o cambio, lista de especies en riesgo. Diario Oficial de la Federación, 30 de diciembre, México D. F.

Shaffer M.L. 1981. Minimum population sizes for species conservation. BioScience 31:131-134.

Slatkin M. 1995. A measure of population subdivision based on microsatellite allele frequencies. Genetics 139:457-462.

Traill L.W., Bradshaw C.J.A. and Brook B.W. 2007. Minimum viable population size: a meta-analysis of 30 years of published estimates. Biological Conservation 139:159-166.

Trejo I. and Dirzo R. 2000. Deforestation of seasonally dry tropical forest: A national and local analysis in Mexico. Biological Conservation 94:133-142.

Van Oosterhout C., Hutchinson W.F. and Wills D.P.M. and Shipley P. 2004. MICRO-CHEKER: software for identifying and correcting genotyping errors in microsatellite data. Molecular Ecology Notes 4:535538.

Vergeer P., Rengelink R., Copal A. and Ouborg N.J. 2003. The interacting effects of genetic variation, habitat quality and population size on performance of Succisa ratensis. Journal of Ecology 91:18-26.

Vester H.F.M., Lawrence D., Eastman J.R., Turner II B.L., Calmé S., Dickson R., Pozo C. and Sangermano F. 2007. Land change in southern Yucatan and Calakmul biosphere reserve: Effects on habitat and biodiversity. Ecological Applications 17:989-1003.

Vivero J.L., Szejner M., Gordon J. and Magin G. 2006. The Red List of Trees of Guatemala. Fauna and Flora International, Botanic Gardens Conservation International, The Global Trees Campaign, The IUCN/SSC Global Tree Specialist, Cambridge. Available at: http://www.ecolex.org/server2.php/libcat/ docs/LI/MON-080203.pdf. Consulted 01 February 2010

Waples R.S. 2006. A bias correction for estimates of effective population size based on linkage disequilibrium at unlinked gene loci. Conservation Genetics 7:167-184.

Waples R.S. and Do C. 2008. LDNe: a program for estimating effective population size from data on linkage disequilibrium. Molecular Ecology Resources 8:753-756.

Wendelken P.W. and Martin R.F. 1987. Avian consumption of Guaiacum sanctum fruit in the arid interior of Guatemala. Biotropica 19:116-121.

White D.A. and Hood C.S. 2004. Vegetation patterns and environmental gradients in tropical dry forests of the northern Yucatan Peninsula. Journal of Vegetation Science 15:151-160.

Williamson-Natesan E.G. 2005. Comparison of methods for detecting bottlenecks from microsatellite loci. Conservation Genetics 6:551-562.

Young A.G. and Clarke G.M. 2000. Genetics, Demography and Viability of Fragmented Populations, Conservation Biology 4. Cambridge University Press, Cambridge.

Young A.G. and Pickup M. 2010. Low S allele numbers limit mate availability, reduce seed set and skew fitness in small populations of a self-incompatible plant. Journal of Applied Ecology 47:541-548. 